\title{
MINI TOMATO CULTIVARS FOR THE SUB-MID SÃO FRANCISCO VALLEY, BRAZIL $^{1}$
}

\author{
JONY EISHI YURI ${ }^{2 *}$, NIVALDO DUARTE COSTA $^{2}$, MARIA AUXILIADORA COÊLHO DE LIMA $^{2}$, GERALDO \\ MILANEZ DE RESENDE ${ }^{2}$, TAINÁ DOURADO FERREIRA ${ }^{3}$, MIRIAM CLEBIA SILVA ${ }^{3}$
}

\begin{abstract}
Two experiments were conducted in Petrolina, State of Pernambuco (PE), Brazil, in order to evaluate the performance of mini tomato cultivars under the conditions of the Sub-Mid São Francisco Valley. One on crops of the second half of the year (SH) from August to December 2012, and other on crops of the first half of the year (FH) from March to July 2013. Six mini tomato cultivars were evaluated in both seasons: E5663, Kada, F1170, Tanzimech, E1275 and Abirú. A randomized block experimental design was used, with four replications, arranged in split plot, with the growing seasons in the plots and cultivars in the subplots. The total and commercial fruit yield, soluble solid contents, fruit yield per plant, number of fruits per plant, and fruit fresh weight were evaluated. The total yield was higher in the FH, regardless of the cultivar used. The cultivar E5663 presented yield of $40.3 \mathrm{Mg} \mathrm{ha}^{-1}$ in the SH and $104.0 \mathrm{Mg} \mathrm{ha}^{-1}$ in the FH. Commercial yield, soluble solid content and yield per plant followed the same trend. The number of fruits per plant ranged from 390.8 to 941.4 (FH) and from 80.5 to $315.4(\mathrm{SH})$. The cultivar E5663 presented the best yield and soluble solid content responses, thus, it may be recommended for the conditions of Petrolina PE, and can be adopted for planting in both seasons evaluated.
\end{abstract}

Keywords: Solanum lycopersicum L.. Yield. Semiarid region.

\section{CULTIVARES DE MINITOMATE PARA O SUBMÉDIO DO VALE DO SÃO FRANCISCO}

RESUMO - Dois experimentos foram conduzidos em Petrolina PE, com o objetivo de avaliar o comportamento produtivo de cultivares de minitomate, nas condições do Submédio do Vale do São Francisco. O primeiro, entre agosto e dezembro de 2012 (segundo semestre), e o segundo, entre março e julho de 2013 (primeiro semestre). Para as duas épocas, foram avaliados seis cultivares de minitomate: E5663; Kada; F1170; Tanzimech; E1275 e Abirú. O delineamento experimental foi de blocos casualizados, com quatro repetições dispostas em parcelas subdivididas, testando-se nas parcelas as duas épocas de cultivo e nas subparcelas, os genótipos. Avaliou-se produtividade total e comercial de frutos, teor de sólidos solúveis, número de frutos por planta, massa fresca de frutos por planta e massa fresca de fruto. A produtividade total, independentemente do genótipo, no cultivo de primeiro semestre foi superior. No cultivo de segundo semestre, a cultivar E5663 apresentou produtividade de $40,3 \mathrm{Mg} \mathrm{ha}^{-1}$. No primeiro semestre, com esse mesmo genótipo, obteve-se produtividade de 104,0 $\mathrm{Mg} \mathrm{ha}^{-1}$. A produtividade comercial, o teor de sólidos solúveis e a produção por planta seguiram a mesma tendência. Quanto ao número de frutos por planta, foi verificada uma variação de 390,8 a 941,4 e 80,5 a 315,4 frutos por planta, para o primeiro semestre e segundo semestre, respectivamente. $\mathrm{O}$ genótipo E5663, por ter apresentado as melhores respostas produtivas e teor de sólidos solúveis, pode ser indicado para as condições de Petrolina-PE, ressaltando-se que este pode ser adotado nos dois períodos de cultivo do ano.

Palavras-chave: Solanum lycopersicum L.. Rendimento. Semiárido.

\footnotetext{
*Corresponding author

${ }^{1}$ Received for publication in 08/26/2014; accepted in 06/27/2016.

${ }^{2}$ Centro de Pesquisa Agropecuária do Trópico Semiárido, Petrolina, PE, Brazil; jony.yuri@embrapa.br, nivaldo.costa@embrapa.br, auxiliadora.lima@embrapa.br, geraldo.milanez@embrapa.br.

${ }^{3}$ Universidade de Pernambuco, Campus Petrolina, PE, Brazil; taina.dourado@hotmail.com, miriam.clebia@hotmail.com.
} 


\section{INTRODUCTION}

Tomato (Solanum lycopersicum L.) crops in the Brazilian Northeast are conducted mainly by small farmers, especially in the states of Pernambuco, Bahia and Ceará, and has a great socioeconomic importance. Bahia and Pernambuco account for $67.2 \%$ of the total Northeastern production, with approximately $416,700{\mathrm{Mg} \mathrm{yr}^{-1}}^{-}$. The average yield of Pernambuco is $35.3 \mathrm{Mg} \mathrm{ha}^{-1}$ and of Bahia is $40.7 \mathrm{Mg} \mathrm{ha}^{-1}$ (IBGE, 2013).

The Sub-Mid São Francisco Valley was an important tomato production center during the 1990s and early 2000s, however, almost all of those fruits was intended for processing. Thereafter, the tomato processing industry declined, and the few producers who remained, kept the habit of grow the same type of materials (cultivars suitable for processing), despite aiming to supply the fresh consumption market.

Information on the best tomato cultivars for the fresh consumption market, for various edaphoclimatic conditions, are available in the literature (GUSMÃO et al., 2006; PENA et al., 2010), however, for the conditions of the Sub-Mid São Francisco Valley, the works so far, were directed to materials intended for processing.

In this context, the production of special tomatoes, with different shapes and sizes, is an emerging option. According to Azevedo et al. (2010), the mini tomatoes stands out among these special tomatoes. The market value of these tomatoes can reach up to three times the value of other tomato types (SIMONNE et al., 2005; SOUZA, 2007). Mini tomatoes can be classified into two groups, cherry and grape. Simonne et al. (2005) described a typical tomato of the grape group as an oval shaped fruit with weight ranging from 4 to $12 \mathrm{~g}$ per fruit. Tomatoes of the cherry group have fruit weight of 15 to $25 \mathrm{~g}$ (FILGUEIRA, 2008), i.e., more than the fruits of the grape group, despite their more rounded shape.

According to Iba (2002), crop species have variable responses to heat, which is one of the more important factors for the development and selection of more tolerant materials. Thus, experiments at field conditions for select cultivars which are tolerant, especially to heat, are needed and still are a suitable methodology for this purpose (GIORDANO et al., 2005).

Tomato plants cannot develop at extreme temperatures. The temperatures considered as favorable to their proper development and production are between 25 and $30^{\circ} \mathrm{C}$ (daytime) and
15 and $20^{\circ} \mathrm{C}$ (nighttime) (BRANDÃO FILHO; CALLEGARI, 1999). High temperatures, which are unfavorable to the proper development of tomatoes, can cause anomalies such as sunscalds, plant stress and changes in fruit color by reducing lycopene synthesis (SILVA JUNIOR; PRANDO, 1989), resulting in lower pollen grain release and germination, less fruit set, smaller fruits and fruits with few seeds (FONTES; SILVA, 2005). Tomato crops have specific requirements of climatic conditions, thus, locations of low altitudes (below $400 \mathrm{~m}$ ), and hot climate hinder their development, resulting in reduction of fruit yield and quality (SILVA et al., 2011). However, tomato crops have been possible in various regions of Brazil due to works involving genetic improvement and other crop management techniques.

In this context, the objective of this work was to evaluate the performance of mini tomato cultivars of determinate growth habit, in two crop seasons in the conditions of the Sub-Mid São Francisco Valley, Brazil.

\section{MATERIAL AND METHODS}

Two experiments were conducted in the Bebedouro Experimental Station $\left(9^{\circ} 8^{\prime} 8,9^{\prime \prime} \mathrm{S}, 40^{\circ}\right.$ 18 '33,6"W and altitude of $373 \mathrm{~m}$ ) of the Embrapa Semi-Arid in Petrolina, State of Pernambuco (PE), Brazil. One on crops of the second half of the year (SH) from August to December 2012, and other on crops of the first half of the year $(\mathrm{FH})$ from March to July 2013. The region climate is classified as semi-arid BSwh, according to the Köppen classification, with rainfalls concentrated in November to April, average annual precipitation of $500 \mathrm{~mm}$, unevenly distributed, annual relative humidity of $66 \%$, annual average air temperature of $26,5^{\circ} \mathrm{C}$ with the peak between October and December, and its coldest month is July. Meteorological data were collected by an automatic station installed in the experimental field (Figure 1).

The soil of the experimental area was classified as eutrophic Yellow Argisol of sandy texture (EMBRAPA, 2006), with the following chemical characteristics: $\mathrm{P}=51.43 \mathrm{mg} \mathrm{dm}^{-3}$;

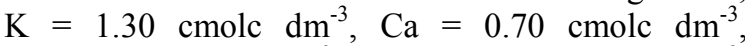
$\mathrm{Mg}=0.40 \mathrm{cmolc} \mathrm{dm}^{-3}, \mathrm{H}+\mathrm{Al}=2.24 \mathrm{cmolc} \mathrm{dm}^{-3}$, effective $\mathrm{CEC}=4.73$ cmolc $\mathrm{dm}^{-3}$, Base Saturation $=52.64, \mathrm{pH}$ in water $(1: 2.5)=6.78$, $\mathrm{B}=0.90 \mathrm{mg} \mathrm{dm}{ }^{-3}, \quad \mathrm{Cu}=0.80 \mathrm{mg} \mathrm{dm}^{-3}$, $\mathrm{Fe}=14.90 \mathrm{mg} \mathrm{dm}^{-3}, \mathrm{Mn}=41.30 \mathrm{mg} \mathrm{dm}^{-3}$, and $\mathrm{Zn}=3.50 \mathrm{mg} \mathrm{dm}^{-3}$. 


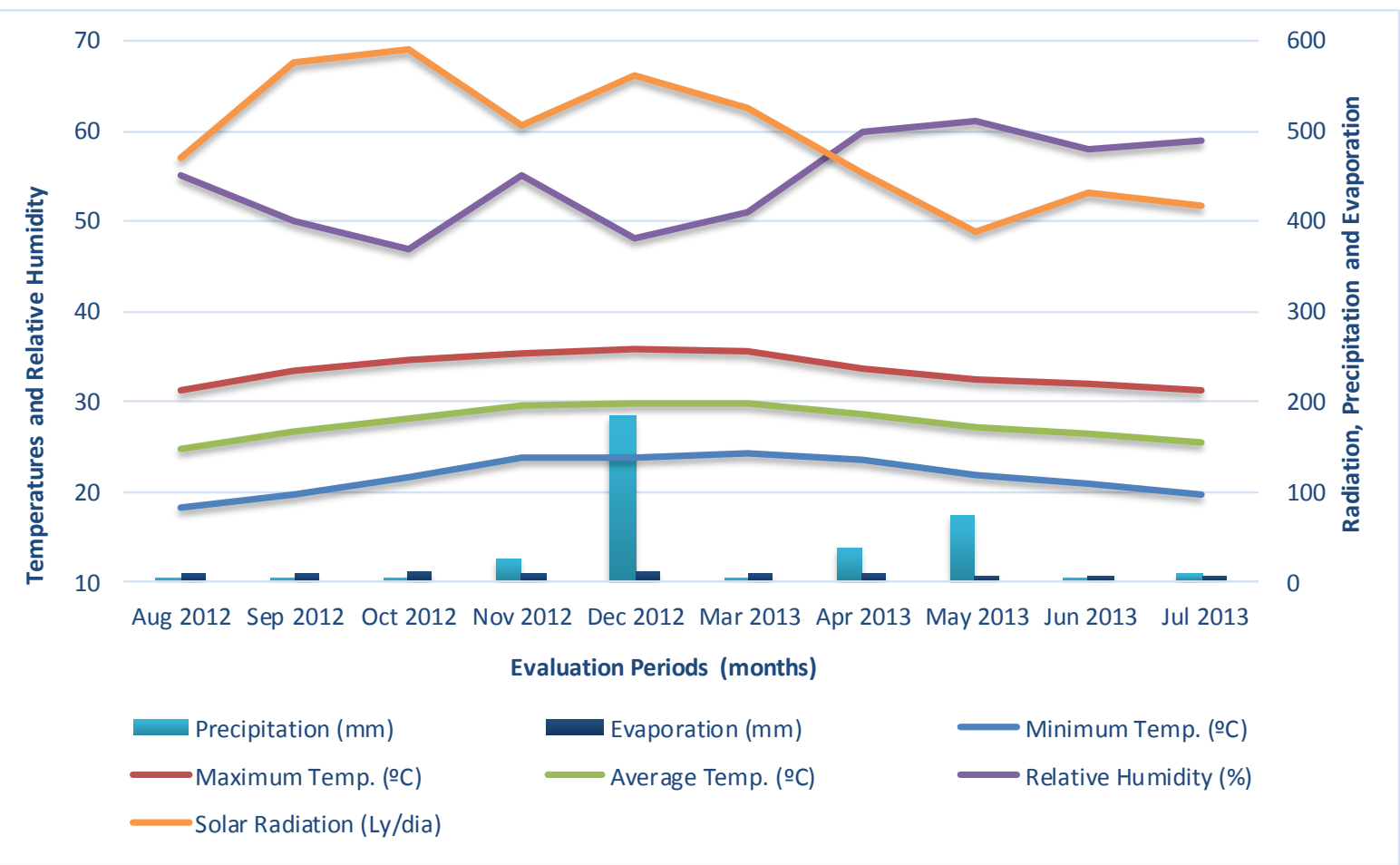

Figure 1. Monthly maximum, minimum and average temperatures, relative humidity, radiation, precipitation and evaporation over the seasons of the two experiments.

Soil preparation for the areas consisted of plowing, harrowing and raising of beds. Fertilization was carried out according to the recommendations of Cavalcante (2008), with $40.0 \mathrm{~kg} \mathrm{ha}^{-1} \mathrm{~N}$ (urea), 60.0 $\mathrm{kg} \mathrm{ha}^{-1}$ of $\mathrm{P}_{2} \mathrm{O}_{5}$ (superphosphate) and $30.0 \mathrm{~kg} \mathrm{ha}^{-1}$ of $\mathrm{K}_{2} \mathrm{O}$ (potassium chloride). The fertilizers were limited to the raised beds and carefully incorporate to a depth of $0.1 \mathrm{~m}$. A drip irrigation line with emitters flow of $1.6 \mathrm{~L} \mathrm{~h}^{-1}$ and nominal diameter of $16 \mathrm{~mm}$, spaced $0.50 \mathrm{~m}$ apart, were installed in each bed. Plastic silver-color films were then used to cover the beds (mulching), which was bored with a $75-\mathrm{mm}$ tube every $0.5 \mathrm{~m}$, spacing the plants $0.5 \mathrm{~m}$ apart and rows $2.0 \mathrm{~m}$ apart. This procedure was similar in the two growing seasons.

Six mini tomato cultivars were evaluated in both seasons: E5663, Kada, F1170, Tanzimech, E1275 and Abirú. A randomized block experimental design was used, with four replications, arranged in split plot, with the growing seasons in the plots and cultivars in the subplots.

Six beds of $35.0 \mathrm{~m}$ were raised, discarding two of each border. Each 5.00-m-length of the beds, with 10 plants, was considered as a subplot. The subplots were spaced $1.0 \mathrm{~m}$ apart to facilitate the viewing of their boundaries. The six central plants of each subplot was evaluated, discarding the two plants from each end. Thus, considering that the beds were spaced $2.0 \mathrm{~m}$ apart, the total area of the experiments was $350.0 \mathrm{~m}^{2}$.

The seedlings used in both experiments were produced in 200-cell polypropylene trays filled with a commercial substrate based on coconut fiber. They were grown in a greenhouse for 25 days, under phytosanitary care and irrigation. Transplanting were carried out on September 08, 2012 for the first experiment and on April 19, 2013 for the second experiment.

The crop was managed with weekly preventive sprayings for pest and disease control. The main phytosanitary problems were related to pests, especially the leafminers and cutworms, for which insecticides based on abamectin, cyromazine, imidaclopid, pyrethroids and methomyl were applied. Fungi control were performed with products based on copper oxcloreto and mamcozeb. The weeds that emerged in the holes of the plastic cover, next to the seedlings were manually eliminated. The topdressing was performed by fertigation with three applications per week, using $120.0 \mathrm{~kg} \mathrm{ha}^{-1}$ of $\mathrm{N}$ (urea), $60.0 \mathrm{~kg}$ ha ${ }^{-1}$ of $\mathrm{P}_{2} \mathrm{O}_{5}$ (monoammonium phosphate) and $30.0 \mathrm{~kg} \mathrm{ha}^{-1}$ of $\mathrm{K}_{2} \mathrm{O}$ (potassium chloride), according to the recommendations of Cavalcante (2008). The water depth of irrigation was calculated according to the reference evapotranspiration measured between irrigations. The plants developed naturally and no staking or thinning practices were adopted, since the cultivars have determinate growth habit.

The fruit harvesting started 65 days after transplanting (DAT), extending for 20 days, with seven crops with 4-day intervals, for the first experiment; and 68 DAT, when the fruits showed signs of maturation, extending for 39 days, for the second experiment. The phenological stages of plants up to the fruiting stage were similar in both 
seasons, however, in the maturation stage, the cycles in the $\mathrm{FH}$ increased, due to the higher temperatures in the $\mathrm{SH}$ and lower in the $\mathrm{FH}$.

The total and commercial fruit yield, soluble solid contents, fruit yield per plant, number of fruits per plant, and fruit fresh weight were evaluated. The data were compared by the $\mathrm{F}$ test at $5 \%$ probability and when significant differences were found between treatments, the averages were compared by the Scott-Knott test at $5 \%$ probability, according to Gomes (2000), using the software SISVAR 4.0 (FERREIRA, 2010).

\section{RESULTS AND DISCUSSION}

The cultivars, growing seasons and their interaction significantly and independently affected the total yield. The results of the first in every season shows that the FH was superior compared to the $\mathrm{SH}$, regardless of the cultivar used. Within each season, the E5663 in the SH was statistically superior to the other cultivars, with yield of $40.3 \mathrm{Mg} \mathrm{ha}^{-1}$. The result of this cultivar in the $\mathrm{SH}$ was above those reported by Silva et al. (2011) for the conditions of Montes Claros, State of Minas Gerais (MG), Brazil, who evaluated different cherry tomato accessions and found total yield of $27.1 \mathrm{Mg} \mathrm{ha}^{-1}$ in $\mathrm{SH}$ for the best accession. The cultivar E5663 showed the highest yield $\left(104.0 \mathrm{Mg} \mathrm{ha}^{-1}\right)$ also in the FH. A significant variation in yield was found between the growing seasons (Table 1), showing the influence of climate on tomato crops (Figure 1).

Table 1. Total and commercial yield and soluble solid contents of mini tomato fruits depending on cultivars and growing seasons, in the first half of the year (FH) and second half of the year (SH), at the conditions of the Sub-Mid São Francisco Valley.

\begin{tabular}{|c|c|c|c|c|c|c|}
\hline \multirow{3}{*}{ Cultivars } & \multicolumn{2}{|c|}{$\begin{array}{l}\text { Total Yield } \\
\left(\mathrm{Mg} \mathrm{ha}^{-1}\right)\end{array}$} & \multicolumn{2}{|c|}{$\begin{array}{l}\text { Commercial Yield } \\
\qquad\left(\mathrm{Mg} \mathrm{ha}^{-1}\right)\end{array}$} & \multicolumn{2}{|c|}{$\begin{array}{l}\text { Soluble Solid Contents } \\
\left({ }^{\circ} \text { Brix }\right)\end{array}$} \\
\hline & \multicolumn{2}{|c|}{ Growing season } & \multicolumn{2}{|c|}{ Growing season } & \multicolumn{2}{|c|}{ Growing season } \\
\hline & FH & SH & $\mathrm{FH}$ & SH & FH & SH \\
\hline$E 5663$ & $104.0 \mathrm{Aa}$ & $40.3 \mathrm{Ab}$ & $99.3 \mathrm{Aa}$ & $39.9 \mathrm{Ab}$ & $5.4 \mathrm{Aa}$ & $5.6 \mathrm{Aa}$ \\
\hline Kada & $43.9 \mathrm{Ca}$ & $27.3 \mathrm{Bb}$ & $41.6 \mathrm{Ca}$ & $27.2 \mathrm{Bb}$ & $5.5 \mathrm{Aa}$ & $4.5 \mathrm{Bb}$ \\
\hline$F 1170$ & $97.8 \mathrm{Ba}$ & $24.9 \mathrm{Bb}$ & $92.1 \mathrm{Ba}$ & $21.9 \mathrm{Bb}$ & $5.0 \mathrm{Ba}$ & $5.0 \mathrm{Ba}$ \\
\hline Tanzimech & $47.0 \mathrm{Ca}$ & $22.6 \mathrm{Bb}$ & $43.1 \mathrm{Ca}$ & $21.3 \mathrm{Bb}$ & $5.9 \mathrm{Aa}$ & $4.8 \mathrm{Bb}$ \\
\hline E1275 & $93.1 \mathrm{Ba}$ & $18.3 \mathrm{Cb}$ & $89.9 \mathrm{Ba}$ & $17.9 \mathrm{Bb}$ & $4.6 \mathrm{Ba}$ & $3.3 \mathrm{Cb}$ \\
\hline Abirú & $92.5 \mathrm{Ba}$ & $17.7 \mathrm{Cb}$ & $89.1 \mathrm{Ba}$ & $17.5 \mathrm{Bb}$ & $6.0 \mathrm{Aa}$ & $5.8 \mathrm{Aa}$ \\
\hline${ }^{3} \mathrm{CV}(\%)$ & \multicolumn{2}{|c|}{9.66} & \multicolumn{2}{|c|}{9.39} & \multicolumn{2}{|c|}{7.88} \\
\hline
\end{tabular}

Means followed by the same uppercase letter in the columns or the same lowercase letter in the lines do not differ by the Scott-Knott test at $5 \%$ of probability. CV $(\%)=$ coefficient of variation.

Temperatures below $10^{\circ} \mathrm{C}$ or above $30^{\circ} \mathrm{C}$, in general, harm the fruit set (PICKEN, 1984). Tomato plants typically show reduced number of fruits and lower yield due to high temperatures. However, the results showed that the fruit set capacity is also affected by the tolerance of each cultivar to high temperatures. According to Santos (2010), high temperatures induce morphological and physiological disorders in floral structures of tomato, resulting in lower yield due to high rates of fruit abortion and malformation. A significant fall of flowers occurs when the temperature reaches $27^{\circ} \mathrm{C}$ to $30^{\circ} \mathrm{C}$ (daytime) and $20^{\circ} \mathrm{C}$ (nighttime).

The fruit commercial yield was also significantly affected by the cultivar, growing season and their interaction (Table 1), and similarly to the total yield, statistically higher for the cultivar E5663 in both growing seasons, with $39.9 \mathrm{Mg} \mathrm{ha}^{-1}$ in the $\mathrm{SH}$ and $99.3 \mathrm{Mg} \mathrm{ha}^{-1}$ in the $\mathrm{FH}$, i.e., an increase of $249 \%$. According to the performance of the cultivars within the growing seasons, all cultivars had better performance in the $\mathrm{FH}$ conditions.

The effect of adverse temperatures in the fruit set is usually found in the Brazilian Northeast in summer crops, especially in the São Francisco
Valley, and in the South, in winter crops and early spring. The high temperatures and humidity in the rainy season cause more phytosanitary problems, with greater need for pesticide applications and cultural practices, which increases the production costs and decreases the fruit yield and quality. Therefore, the best tomato prices are found in this season (SEDIYAMA et al., 2003). The average commercial yield of the best materials in the $\mathrm{FH}$ were higher than those obtained in the Brazilian Southeast $\left(65.5 \mathrm{Mg} \quad \mathrm{ha}^{-1}\right)$ and Midwest (75.2 $\mathrm{Mg} \mathrm{ha}^{-1}$ ) (LSPA, 2010).

The interaction between the cultivars and growing seasons significantly affected the total solid contents (Table 1). According to the performance of the cultivars in the $\mathrm{SH}$ conditions, the highest total solid contents was found in the cultivars Abirú (5.8 ${ }^{\circ}$ Brix) and E5663 (5.6 ${ }^{\circ}$ Brix), which were statistically higher than the contents in the other cultivars. The E5663 was superior to the other cultivars, presenting higher yield at different temperature conditions, while Abirú had its best performance at milder temperatures, without loss of the fruit commercial quality, which is mainly assessed by soluble solids. On the other hand, in the 
FH conditions, the cultivars Abirú, E5663, and also Kada and Tanzimech had relatively higher soluble solid contents. However, these materials are not recommended to the regional conditions studied, due to their low yield potential. The results found in the present work were similar to those observed by Sobreira et al. (2010), who evaluated several mini tomato accessions and found soluble solid contents ranging from 5.4 to $6.6^{\circ} \mathrm{Brix}$; and higher than those found by Silva et al. (2011) for the conditions of Montes Claros MG, who evaluated different mini tomato strains and reported $5.0^{\circ} \mathrm{Brix}$ as the higher result.

According to the results of each cultivar within the growing seasons, E5663, F1170 and Abirú had no significant differences in soluble solids, while
Kada, Tanzimech and E1275 had higher soluble solids in the $\mathrm{SH}$.

Similarly, the fruit yield per plant, number of fruits per plant and fruit weight were also significantly affected by the cultivars, growing seasons and their interaction (Table 2). All cultivars showed better results of fruit yield per plant in the FH. Within the growing seasons, the cultivars E5663 had the highest yield with $8.3 \mathrm{~kg}$ per plant in the $\mathrm{FH}$ and $3.2 \mathrm{~kg}$ per plant in the $\mathrm{SH}$. This great difference between growing seasons confirms that the environmental conditions affects the development and production of mini tomatoes. According to Fontes and Silva (2005), temperatures above the ideal cause stress to plants, reducing their pollination and fruit set capacity.

Table 2. Fruit yield per plant, number of fruits per plant and fruit fresh weight of mini tomato depending on cultivars and growing seasons, in the first half of the year $(\mathrm{FH})$ and second half of the year $(\mathrm{SH})$, at the conditions of the Sub-Mid São Francisco Valley.

\begin{tabular}{|c|c|c|c|c|c|c|}
\hline \multirow{3}{*}{ Cultivars } & \multirow{2}{*}{\multicolumn{2}{|c|}{$\begin{array}{c}\begin{array}{c}\text { Fruit yield } \\
\text { (kg per planta) }\end{array} \\
\text { Growing season } \\
\end{array}$}} & \multicolumn{2}{|c|}{ Number of fruits per plant } & \multicolumn{2}{|c|}{$\begin{array}{l}\text { Fruit fresh weight } \\
\text { (g per fruit) }\end{array}$} \\
\hline & & & \multicolumn{2}{|c|}{ Growing season } & \multicolumn{2}{|c|}{ Growing season } \\
\hline & FH & $\mathrm{SH}$ & FH & $\mathrm{SH}$ & FH & $\mathrm{SH}$ \\
\hline$E 5663$ & $8.3 \mathrm{Aa}$ & $3.2 \mathrm{Ab}$ & $821.0 \mathrm{Ba}$ & $315.4 \mathrm{Ab}$ & $10.2 \mathrm{Aa}$ & $10.2 \mathrm{Ba}$ \\
\hline Kada & $3.5 \mathrm{Ca}$ & $2.2 \mathrm{Bb}$ & $390.8 \mathrm{Ca}$ & $302.0 \mathrm{Aa}$ & $9.0 \mathrm{Aa}$ & $7.2 \mathrm{Ca}$ \\
\hline$F 1170$ & $7.8 \mathrm{Ba}$ & $1.9 \mathrm{Bb}$ & $741.5 \mathrm{Ba}$ & $174.6 \mathrm{Bb}$ & $10.6 \mathrm{Aa}$ & $11.4 \mathrm{Ba}$ \\
\hline Tanzimech & $3.7 \mathrm{Ca}$ & $1.8 \mathrm{Bb}$ & $288.3 \mathrm{Ca}$ & $80.5 \mathrm{Bb}$ & $13.0 \mathrm{Ab}$ & $23.9 \mathrm{Aa}$ \\
\hline E1275 & $7.5 \mathrm{Ba}$ & $1.5 \mathrm{Cb}$ & 941.4 Aa & 186.3 Bb & $8.2 \mathrm{Aa}$ & $8.1 \mathrm{Ca}$ \\
\hline Abirú & $7.4 \mathrm{Ba}$ & $1.4 \mathrm{Cb}$ & $763.4 \mathrm{Ba}$ & $122.0 \mathrm{Bb}$ & $9.6 \mathrm{Aa}$ & $12.6 \mathrm{Ba}$ \\
\hline C.V. $(\%)$ & \multicolumn{2}{|c|}{9.67} & \multicolumn{2}{|c|}{18.53} & \multicolumn{2}{|c|}{24.22} \\
\hline
\end{tabular}

Means followed by the same uppercase letter in the columns or the same lowercase letter in the lines do not differ by the Scott-Knott test at $5 \%$ of probability. CV $(\%)=$ coefficient of variation.

The number of fruits per plant in the $\mathrm{FH}$ ranged from 288.3 to 941.4 , while, in the $\mathrm{SH}$, the values were much lower, from 80.5 to 315.4 . These results were similar to those found by Silva et al. (2011) (30.2 to 304.3 fruits per plant), who evaluated different mini tomato strains with harvests in September and October in the conditions Montes Claros MG. All cultivars had higher number of fruits in the FH.

The average fruit fresh weight in the $\mathrm{FH}$ ranged from 8.2 to $13.0 \mathrm{~g}$ per fruit, with no significant differences between cultivars. However, in the $\mathrm{SH}$, significant differences between the materials were found, with the cultivar Tamzimech presenting greater weight (23.9 g per fruit) and Kada presenting the lower (7.2 g per fruit). The values obtained in the present work are considered within the appropriate weight range of mini tomatoes (SIMONNE et al., 2005; FILGUEIRA, 2008).

\section{CONCLUSION}

The cultivar E5663 had the best yield responses, fruit weight and soluble solid contents and may be recommended for the conditions of the Sub-Mid São Francisco Valley, in both periods of the year, although, for crops in the second half of the year, fruit yield and quality may be relatively lower than in the crops in the first half of the year.

\section{REFERENCES}

AZEVEDO, V. F.; ABBOUD, A. C. S.; CARMO, M. G. F. Row spacing and pruning regimes on organically grown cherry tomato. Horticultura Brasileira, Brasília, v. 28, n. 4, p.389-394, 2010.

BRANDÃO FILHO, J. U. T; CALLEGARI, O. Cultivo de hortaliças de frutos em solo em ambiente protegido. Informe Agropecuário, Belo Horizonte, v. 20, n. 200/201, p. 64-68, 1999.

CAVAlCANTE, F. J. A. (Coord.). Recomendações de adubação para o estado de Pernambuco: $2^{\text {a }}$ aproximação. Recife, PE: IPA, 2008. 212 p.

EMBRAPA. Centro Nacional de Pesquisa de Solos. Sistema brasileiro de classificação de solos. $2^{\mathrm{a}}$. ed. 
Rio de Janeiro, RJ: Embrapa Solos, 2006. 306 p.

FERREIRA, D. F. SISVAR Versão 5.3. Lavras: Departamento de Ciências Exatas, UFLA. 2010.

FILGUEIRA, F. A. R. Novo manual de olericultura: agrotecnologia moderna na produção e comercialização de hortaliças. Viçosa, MG: Editora UFV, 2008. $421 \mathrm{p}$.

FONTES, P. C. R.; SILVA, D. J. H. Cultura do tomate. In: FONTES, P. C. R. (Ed.). Olericultura: teoria e pratica. 1 ed. Viçosa: Editora UFV, 2005. cap. 29 , p. $457-475$.

GIORDANO, L. B. et al. Seleção de linhagens com tolerância ao calor em germoplasma de tomateiro coletada na região Norte do Brasil. Horticultura Brasileira, Brasília, v. 23, n. 1, p. 105-107, 2005.

GOMES, F. P. Curso de estatística experimental. 14. ed. São Paulo, SP: NOBEL, 2000. 477 p.

GUSMÃO, M. T. A.; GUSMÃO, S. A. L.; ARAÚJO, J. A. C. Produtividade de tomate tipo cereja cultivado em ambiente protegido e em diferentes substratos. Horticultura Brasileira, Brasília, v. 24, n. 4, p. 431-436, 2006.

IBA, K. Aclimative response to temperature stress in higher plants: approaches of gene engineering for temperature tolerance. Annual Review Plant Biology, Palo alto, v. 53, p. 225-245, 2002.

INSTITUTO BRASILEIRO DE GEOGRAFIA E Sistemático da Produção Agrícola. Rio de Janeiro, v. 26. p. 1-86, 2013.

LSPA: Levantamento Sistemático da Produção Agrícola. Rio de Janeiro, v. 23, p. 1-80, 2010.

PENA, M. A. N. A. et al. Adaptabilidade e estabilidade de genótipos de tomateiro sob cultivo em solo de terra firme e várzea da Amazônia infestados por Ralstonia solanacearum. Bragantia, Campinas, v. 69, n. 1, p. 27-37, 2010.

PICKEN, A. J. F. A review of pollination and fruit set in the tomato (Lycopersicon esculentum Mill.). Journal Horticultural Science, Ashford, v. 59, n. 1, p. 1-13, 1984.

SANTOS, L. S. Murcha bacteriana, tolerância a altas temperaturas e pegamento de frutos em tomateiro. 2010. 16 f. Monografia (Graduação em Agronomia) - Universidade Federal Rural de Pernambuco, Recife, 2010.
D. J. H. Práticas culturais adequadas ao tomateiro. Informe Agropecuário, Belo horizonte, v. 24, n. 219, p. 19-25, 2003.

SILVA JUNIOR, A. A.; PRANDO, H. F. Cultivares e épocas de semeadura de tomate para o litoral catarinense. Agropecuária Catarinense, Florianópolis, v. 9, n. 4, p. 48-50, 1989.

SIMONNE, E. et al. Field performance, chemical composition and sensory evaluation of red and yellow grape tomato varieties. Proceedings Florida State Horticultural Society, Tallahassee, v. 118, p. 376-378, 2005.

SILVA, A. C. et al.Avaliação de linhagens de tomate cereja tolerantes ao calor sob sistema orgânico de produção. Revista Caatinga, Mossoró, v. 24, n. 3, p. $33-40,2011$.

SOBREIRA, F. M. et al. Qualidade de sabor de tomates dos tipos salada e cereja e sua relação com caracteres morfoagronômicos dos frutos. Revista Ciência e Agrotecnologia, Lavras, v. 34, n. 4, p. 1015-1023, 2010.

SOUZA, N. Tomate mais doce e sem acidez. Jornal O Estado de São Paulo. São Paulo, 8 p., jun. 2007. 